\title{
PENGARUH PEMBERIAN PAKAN BUATAN DARI KOMBINASI TEPUNG CACING TANAH (Lumbricus rubellus) DAN TEPUNG DAUN PEPAYA TERHADAP PERTUMBUHAN IKAN NILA (Oreochromis niloticus)
}

\section{Effect of Artificial Feed Combination of Earthworm Meal (Lumbricus rubellus) and Papaya Leaf Meal on the Growth Out of Tilapia (Oreochromis niloticus)}

\author{
Rukisah*1, Ricky F. Simanjuntak $^{1}$, Wulan Anugrah ${ }^{2}$ \\ ${ }^{1}$ Jurusan Akuakultur, Universitas Borneo Tarakan, \\ Jalan Amal Lama Nomor 1, Tarakan, Indonesia \\ ${ }^{2}$ Mahasiswa Jurusan Akuakultur, Universitas Borneo Tarakan, \\ Jalan Amal Lama Nomor 1, Tarakan, Indonesia \\ *e-mail: kichafishery@gmail.com
}

\begin{abstract}
ABSTRAK
Permasalahan yang sering muncul dalam budidaya ikan nila adalah rendahnya pertumbuhan ikan yang disebabkan oleh pemberian pakan yang mengandung energi tinggi tetapi tidak mampu dicerna oleh ikan Pemanfaatan pakan komersil sebagai pakan terhadap pertumbuhan ikan nila kurang efektif karena pakan tersebut masih kompleks sehingga membutuhkan energi untuk diuraikan menjadi lebih sederhana. Metode yang digunakan dalam penelitian ini ialah Rancangan Acak Lengkap (RAL) yang kemudian dianalisis menggunakan sidik ragam one way ANOVA. Hasil terbaik diperoleh pada perlakuan 4 dengan nilai bobot mutlak sebesar 2.97, panjang mutlak sebesar 1.19, laju pertumbuhan spesifik sebesar 2.75, kelangsungan hidup sebesar $83.33 \%$ dan konversi pakan sebesar $0.95 \%$. Berdasarkan hasil penelitian maka dapat disimpulkan bahwa pemberian tepung cacing tanah dan tepung daun pepaya mampu meningkatkan pertumbuhan ikan nila, dimana pertumbuhan optimum ikan nila terdapat pada perlakuan 4.
\end{abstract}

Kata kunci: Cacing Tanah, Kombinasi; Pakan Buatan; Pertumbuhan Ikan Nila; Tepung Daun Pepaya

\begin{abstract}
The problem that often arises in tilapia cultivation is the low growth of fish caused by the provision of feed that contains high energy but cannot be digested by fish. Utilization of commercial feed as feed for tilapia growth is less effective because the feed is still complex so it requires energy to be broken down into more simple. The method used in this study was a completely randomized design (CRD) which was then analyzed using one way ANOVA variance. The best results were obtained in treatment 4 with an absolute weight value of 2.97, absolute length of 1.19 , specific growth rate of 2.75 , survival rate of $83.33 \%$ and feed conversion ratio of $0.95 \%$. Based on the results, it can be concluded that the administration of earthworm meal and papaya leaf meal is able to increase the growth out of tilapia, where the optimum growth out of tilapia is found in the P4.
\end{abstract}

Keywords: Artificial Feed; Combination; Earthworm; Papaya Leaf Meal; Tilapia Growth 


\section{PENDAHULUAN}

Ikan nila merupakan salah satu jenis ikan yang mempunyai nilai ekonomis tinggi dan merupakan komoditas penting dalam bisnis ikan air tawar (Simanjuntak, et al, 2018). Beberapa hal yang mendukung pentingnya komoditas ikan nila, antara lain memiliki resistensin yang relatif tinggi terhadap kualitas penyakit, memiliki toleransi yang luas terhadap kondisi lingkungan, memiliki kemampuan tumbuh yang baik.

Berdasarkan data KKP (2019), selama kurun waktu 2015-2018 produksi ikan nila secara nasional mengalami peningkatan sebesar $12.85 \%$. Pada tahun 2015 produksi ikan nila sebesar 1.084 juta ton, produksi ikan nila sebanyak 1.114 juta ton pada tahun 2016 sedangkan tahun 2017 meningkat menjadi 1.265 juta ton. Produksi hingga triwulan ke III tahun 2018 tercatat 579.688 ton. Hal ini berbanding lurus dengan permintaan pasar yang semakin meningkat, sehingga potensi pasar untuk permintaan ikan nila cukup tinggi.

Peningkatan produksi ikan nila tidak terlepas dari kebutuhan pakan dalam budidaya perikanan. Peningkatan produtivitas yang tinggi dibutuhkan pakan dengan kualitas yang baik (Awaludin et al, 2020). Disisi lain, Indonesia memiliki ketergantungan terhadap bahan baku impor (Simanjuntak dan Ridwansyah, 2020). Salah satu metode yang telah diterapkan ialah pembuatan pakan alternatif dari bahan baku yang memiliki kelimpahan tinggi. Hal tersebut bertujuan untuk mengurangi penggunaan bahan baku pakan impor dan meningkatkan proses pencernaan menjadi lebih mudah sehingga pertumbuhan ikan akan meningkat (Simanjuntak et al., 2018)

Pemanfaatan pakan komersil sebagai pakan terhadap pertumbuhan ikan nila kurang efektif karena pakan tersebut masih kompleks sehingga membutuhkan energi untuk diuraikan menjadi lebih sederhana dan dapat diserap langsung oleh usus (Riyanti, 2014). Selain itu, pakan komersil memiliki kandungan protein sekitar 26-
$30 \%$, sehingga jika manajemen pemberian pakan kurang baik maka dapat menyebabkan akumulasi amonia yang mempercepat penurunan kualitas air (Stickney dan Rohmana, 2009).

Pada umumnya, efisiensi pakan dan pertumbuhan dijadikan dasar untuk pemilihan kadar protein pakan (Azis dan Simanjuntak, 2019). Maka, penggunaan bahan alternatif yang kaya protein dan enzim akan sangat penting guna mendukng pertumbuhan ikan budidaya. Salah satunya dengan menggunakan tepung cacing tanah dan tepung daun pepaya. Dimana tepung cacing tanah tidak membutuhkan waktu lama untuk proses pembuatannya dan juga kandungan protein yang tinggi sekitar $79.45 \%$. Penggunaan cacing sebagai pakan ikan merupakan sumber protein untuk pertumbuhan dan perkembangan ikan. Pemberian tepung cacing meningkatkan retensi protein pada bibit ikan, (Natricia et $a l .$, 2012). Begitu juga dengan daun pepaya terkandung senyawa alkaloid karpain, caricaksantin, violaksanti, papain, saponin flavonoida, dan politenol. Daun pepaya juga mengandung protein tinggi, lemak, vitamin, kalsium $(\mathrm{Ca})$ dan zat besi $(\mathrm{Fe})$ yang berfungsi sebagai pembentukan hemoglobin (Tietze, 1997). Papain sendiri merupakan enzim yang bersifat proteolitik dan mampu menghidrolisasi protein menjadi unsur-unsur sederhana yaitu peptida hingga asam amino (Wariso, 2003). Maka formulasi tepung cacing tanah dengan tepung daun pepaya terhadap peningkatan pertumbuhan ikan nila perlu untuk dilakukan dengan harapan adalah pakan hasil kombinasi tersebut dapat dijadikan alternatif formulasi pakan yang baik bagi para petani budidaya

\section{METODOLOGI}

\section{Waktu dan tempat}

Penelitian ini dilaksanakan pada bulan Januari 2020 - Desember 2020, di Laboratorium Mini Hatchery Fakultas Perikanan dan Ilmu Kelautan Universitas Borneo Tarakan. 


\section{Alat dan Bahan}

Alat yang digunakan selama penelitian berlangsung seperti akuarium, seser, timbangan, penggaris, ember/baskom, dan selang. Bahan yang digunakan ikan nila, air, pakan komersil dan pakan buatan kombinasi tepung cacing tanah dan tepung daun pepaya.

\section{Metode}

\section{Pembuatan Tepung Daun Pepaya}

Proses pembuatan tepung daun pepaya menggunakan metode penepungan. Daun pepaya diambil sebanyak $2 \mathrm{~kg}$ dikeringkan. Setelah kering daun pepaya (C. papaya) diblender hingga halus, sehingga menjadi serbuk. Daun pepaya yang telah dibelender kemudian diayak dengan ayakan kasar, kemudian diblender lagi sampai lebih halus dari proses pemblenderan pertama, jika telah halus kemudian diayak dengan ayakan halus. Tepung cacing tanah yang dibeli dari produksi di Malang.

\section{Persiapan Media dan Biota}

Persiapan media dan biota hal pertama yang perlu dilakukan yaitu cuci aquarium yang akan digunakan sebagai wadah penelitian. Kemudian isi air sebanyak 20 liter di setiap aquarium. Setiap aquarium diberi aerasi dan dibiarkan menyala. Aklimatisasi ikan selama 30 menit. Setelah itu masukkan ikan di masing-masing aquarium sebanyak 15 ekor.

\section{Aplikasi Pakan}

Pemberian pakan dilakukan secara manual dengan dosis pakan yang telah ditentukan. Pemberian pakan buatan diberikan setiap 2 kali sehari pada pukul 08.00 dan 17.00 WITA sebanyak 5\% dari bobot biomassa ikan (Hazmi, 2020). Pemberian pakan sesuai takaran yang ditentukan agar tidak adanya sisa pakan yang terbuang dan berdampak pada kualitas air.

\section{Pemeliharaan}

Pemeliharaan/penelitian dilakukan selama 1 bulan (30 hari), dengan ikan yang berukuran $4-5 \mathrm{~cm}$. Penyiponan dilakukan setiap hari agar tidak ada penumpukan feses dan sisa makanan pada setiap aquarium. Sampling dilakukan 10 hari sekali, pengamatan dilakukan terhadap perubahan panjang, bobot dan kualitas air seperti $\mathrm{pH}$ dan suhu.

\section{Pengumpulan Data}

Data yang saya dapatkan selama penelitian meliputi data berat mutlak, data panjang mutlak, data laju pertumbuhan spesifik, data kelangsungan hidup, ratio konversi pakan, dan data kualitas air. Data ini akan saya jadikan acuan apakah pakan kombinasi yang saya buat memberi pengaruh nyata terhadap pertumbuhan ikan nila.

\section{Formulasi Pakan}

Formulasi pakan yang digunakan ialah $70 \%$ tepung cacing tanah $30 \%$ tepung daun pepaya. Dengan perhitungan setiap $70 \%$ tepung cacing tanah dengan 30\% tepung daun pepaya dikali dengan $150 \mathrm{gr}$ pakan komersil sehingga mendapatkan formulasi $105 \mathrm{gr}$ tepung cacing tanah, $45 \mathrm{gr}$ tepung daun pepaya yang kemudian ditambahkan pakan komersil sebanyak $150 \mathrm{gr}$ dan di campur sehingga mendapatkan komposisi pakan untuk perlakuan 2 begitu juga untuk pelakuan 3, dan 4 (Mahir, 2020).

\section{Rancangan Percobaan}

Penelitian ini menggunakan Rancangan Acak Lengkap (RAL) dengan empat perlakuan tiga ulangan. Adapun Rincian perlakuannya sebagai berikut:

1: Pakan komersil tanpa campuran pakankombinasi

2: Pakan kombinasi (Tepung cacing tanah $70 \%$ + Tepung daun pepaya $30 \%)+$ 150 gr pakan komersil

3: Pakan kombinasi (Tepung cacing tanah $50 \%$ + Tepung daun pepaya $50 \%)+$ 150 gr pakan komersil

4: Pakan kombinasi (Tepung cacing tanah $30 \%+$ Tepung daun pepaya $70 \%$ )+ 150 gr pakan komersil. 
Parameter Yang Diukur

Berat Mutlak

Rumus yang digunakan untuk menghitung pertumbuhan bobot menurut Effendie (2002) adalah:

$$
\boldsymbol{W}=\boldsymbol{W t}-\boldsymbol{W o}
$$

Keterangan :

W : Pertumbuhan bobot mutlak (g)

Wt : Bobot ikan akhir $(\mathrm{g})$

Wo : Bobot ikan awal (g)

\section{Panjang Mutlak}

Rumus yang digunakan untuk menghitung pertumbuhan panjang menurut Effendie (2002) adalah :

$$
\boldsymbol{L}=\boldsymbol{L} \boldsymbol{t}-\boldsymbol{L o}
$$

Keterangan :

L : Pertumbuhan panjang $(\mathrm{cm})$

Lt : Panjang ikan akhir $(\mathrm{cm})$

Lo : Panjang ikan awal (cm)

\section{Laju Pertumbuhan Spesifik}

Laju Pertumbuhan Spesifik/Spesific Growth Rate (SGR) dapat diketahui dengan perhitungan melalui rumus:

$$
\text { SGR = (LnWt-LnWo }) / t \text { x 100\% }
$$

Keterangan:

SGR : Laju Pertumbuhan Spesifik

Wo : Berat hari ke $0(\mathrm{~g})$

$\mathrm{Wt}$ : Berat hari ke $\mathrm{t}(\mathrm{g})$

t : Lama Pemeliharaan (hari)

\section{Kelangsungan Hidup (SR)}

Sintasan / Survival Rate (SR) merupakan persentase jumlah ikan yang hidup pada setiap akuarium pada akhir perlakuan (Wirabakti, 2006).

\section{$\mathrm{SR}=\mathrm{Nt} / \mathrm{No} \times \mathbf{1 0 0 \%}$}

\section{Keterangan :}

SR : Survival Rate / sintasan

$\mathrm{Nt}$ : Jumlah ikan yang hidup selama penelitian (ekor), waktu dalam t

No: Jumlah ikan yang ditebar pada awal penelitian (ekor), $\mathrm{t}=0$

\section{Perhitungan Feed Convertion Ratio (FCR)}

Formulasi yang digunakan untuk menghitung FCR pakan menurut Djajasewaka (1985) sebagai berikut:

$$
\mathbf{F C R}=\frac{\mathbf{F}}{\mathbf{W t}+\mathbf{D}-\mathbf{W o}_{\mathbf{0}}}
$$

Keterangan:

FCR : Rasio konversi pakan

F : Berat pakan yang diberikan (gram)

Wt : Biomassa hewan uji pada akhir pemeliharaan (gram)

D : Bobot ikan mati (gram)

Wo : Biomassa hewan uji pada awal pemeliharaan (gram)

\section{Analisis Data}

Data pertumbuhan, efisiensi pakan dan kelangsungan hidup dianalisis secara statistic pada tingkat kepercayaan 95\% menggunakan analisa sidik ragam. Jika data menunjukkan berpengaruh nyata, dilakukan uji lanjut berdasarkan nilai koefisien keragamannya.

\section{HASIL DAN PEMBAHASAN}

\section{Pertumbuhan Ikan Nila dengan Kombinasi Tepung Cacing Tanah dan Tepung Daun Pepaya}

Berdasarkan pengamatan selama 30 hari penelitian ini menunjukkan bahwa berat mutlak ikan terjadi peningkatan pada perlakuan 4 (2.97 gr). Sedangkan pakan yang memiliki pengaruh terendah adalah perlakuan 2 (2.32). dapat dilihat pada Tabel 1. Hal tersebut menunjukkan bahwa semakin banyak tepung daun pepaya yang ditambahkan kedalam pakan maka akan menghasilkan lebih banyak protein yang dihidrolisis menjadi asam amino, sehingga meningkatkan daya cerna ikan terhadap pakan yang diberikan. Hal tersebut sesuai dengan Wariso (2003) bahwa daun pepaya mengandung enzim papain. Enzim papain merupakan enzi kelompok protease yang berfungsi sebagai agen proteolitik dalam memecah protein pada ikan menjadi peptida atau asam amino sehingga mudah diserap kedalam tubuh ikan. 
Tabel 1. Hasil pertumbuhan pengaruh pemberian pakan buatan kombinasi tepung cacing tanah dan tepung daun pepaya

\begin{tabular}{cccccc}
\hline No & Perlakuan & $\begin{array}{c}\text { Berat Mutlak } \\
(\mathrm{gr})\end{array}$ & $\begin{array}{c}\text { Panjang Mutlak } \\
(\mathrm{cm})\end{array}$ & SGR $(\%)$ & FCR (\%) \\
\hline 1 & 1 & 2.89 & 1.10 & 2.15 & 1.64 \\
2 & 2 & 2.32 & 0.95 & 2.07 & 1.97 \\
3 & 3 & 2.75 & 0.78 & 2.16 & 1.38 \\
4 & 4 & 2.97 & 1.19 & 2.75 & 0.95 \\
\hline
\end{tabular}

Keterangan:

1: Kontrol,

2: Pakan kombinasi (Tepung cacing tanah $70 \%+$ Tepung daun pepaya $30 \%)+150$ gr pakan komersil,

3: Pakan kombinasi (Tepung cacing tanah 50\% + Tepung daun pepaya 50\%)+ 150 gr pakan komersil,

4: Pakan kombinasi (Tepung cacing tanah 30\% + Tepung daun pepaya 70\%)+ 150 gr pakan komersil

Berdasarkan pengamatan selama 30 hari penelitian ini menunjukkan bahwa panjang mutlak ikan terjadi peningkatan pada perlakuan $4(1.19 \mathrm{~cm})$. Sedangkan pakan yang memiliki pengaruh terendah adalah perlakuan $3(0.78 \mathrm{~cm})$ (Tabel 1). Hal ini disebabkan karena daun pepaya yang mengandung enzim papain yang terdapat pada tepung daun pepaya bekerja secara optimal pada konsentrasi $70 \%$ di dalam tubuh ikan. Hasan (2000), menyatakan bahwa kehadiran enzim pada pakan buatan dapat membantu dan mempercepat proses pencernaan sehingga nutrisi dapat cukup tersedia untuk pertumbuhan berat dan panjang ikan. Hal tersebut sesuai dengan pendapat Simanjuntak et al., 2018 bahwa pemberian tepung buah pepaya yang mengandung enzim papain dapat meningkatkan pertumbuhan ikan nila melalui proses proteolitik.

Berdasarkan pengamatan selama penelitian menunjukkan bahwa laju pertumbuhan spesifik ikan terjadi peningkatan pada perlakuan $4(2.75 \%)$. Sedangkan pemberian kombinasi pakan yang memiliki pengaruh terendah terhadap laju pertumbuhan spesifik terdapat perlakuan $1(2.15 \%)$ (Tabel 1). Hal ini menunjukkan bahwa ikan nila dapat memanfaatkan pakan yang diberikan dengan baik karena dukungan aktifitas enzim papain yang berasal dari tepung daun pepaya dalam pakan formulasi. Efisiensi pakan yang tinggi menunjukkan penggunaan pakan yang efisien, sehingga hanya sedikit zat makanan yang dirombak untuk memenuhi kebutuhan energi dan selebihnya digunakan untuk pertumbuhan. Efisiensi pakan merupakan ratio antara pertambahan bobot dengan jumlah pakan yang diberikan selama penelitian (Purbomartono et al., 2019).

Pakan merupakan faktor terpenting dalam budidaya perikanan. Pemberian pakan yang baik juga dapat mempengaruhi laju pertumbuahan spesifik ikan nila. Pakan yang berkualitas memiliki kandungan nutrisi yang lebih baik dalam pertumbuhan. Salah satu faktor utama yang mempengaruhi laju pertumbuhan ikan adalah kualitas dan optimasi dari kuantitas pakan. Berdasarkan hasil pengamatan selama 30 hari masa pemeliharaan terjadi peningkatan bobot rata-rata individu ikan nila pada setiap perlakuan. Hal ini menunjukkan bahwa masing-masing perlakuan dapat memberi pengaruh terhadap pertumbuhan ikan, walaupun tidak begitu signifikan hasilnya. Pengaruh tersebut diduga dapat terjadi karena kandungan gizi masing-masing perlakuan tidak sama dan durasi waktu penelitian yang perlu untuk dievaluasi untuk ditambah.

Berdasarkan pengamatan selama 30 hari penelitian ini menunjukkan bahwa rasio konversi pakan ikan terbaik pada perlakuan $4(0.95 \%)$. Sedangkan pakan yang memiliki pengaruh terendah adalah perlakuan $2(1.97 \%)$ (Tabel 1). Hal tersebut diduga karena optimasi prose proteolitik yang dilakukan oleh enzim papain yang terkandung di dalam tepung daun pepaya 
yang memudahkan proses penyerapan pakan ke dalam tubuh ikan. Nutrisi yang terkandung di dalam pakan telah sesuai dengan kebutuhan nutrisi ikan. Barrows dan Hardy (2001), menyatakan efesiensi pakan yang tinggi menunjukkan penggunaan pakan yang efisien, sehingga hanya sedikit zat makanan yang dirombak untuk memenuhi kebutuhan energi. Nila konversi pakan menunjukkan seberapa besar pakan yang dikonsumsi menjadi biomassa tubuh ikan. semakin rendah nilai rasio pakan maka kualitas pakan yang diberikan semakin baik, hal tersebut diperkuat dengan pernyataan Simanjuntak et., al (2018) bahwa, nilai FCR yang diperoleh pada seluruh perlakuan dapat diakategorikan efektif dikarenakan nilai konversi rasio pakan $<2$.

\section{Kelangsungan Hidup (SR) Ikan Nila}

Berdasarkan pengamatan selama 30 hari penelitian ini menunjukkan bahwa lkelangsungan hidup ikan terjadi peningkatan pada perlakuan $4(83.33 \%)$. Sedangkan pakan yang memiliki pengaruh terendah adalah perlakuan $2(53.33 \%)$ (Gambar 1).

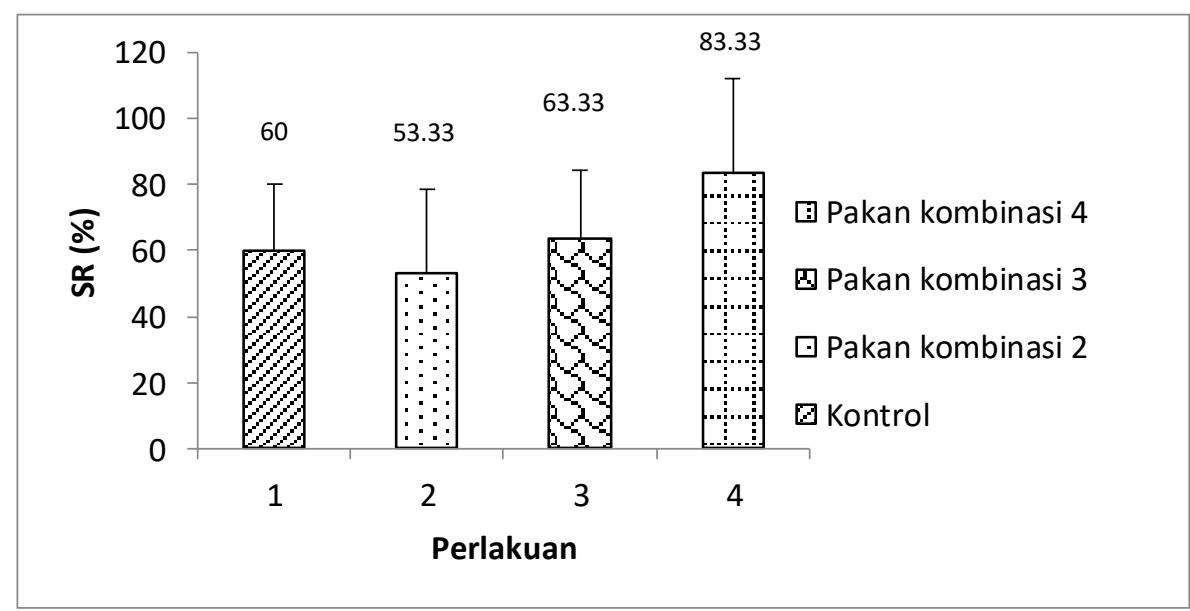

\section{Gambar 1. Kelangsungan Hidup (SR)}

Tingkat kelangsungan hidup tertinggi yang diperoleh dari $\mathrm{P} 4$ diduga hal ini dikarenakan ikan nila baik dalam memanfaatkan pakan yang diberikan dan kualitas air yang terkontrol. Kurangnya pakan yang terbuang media pemeliharaan menunjukkan bahwa pakan yang diberikan sesuai dengan kebutuhan ikan. Kematian ikan terjadi pada awal pemeliharaan ikan. Hal ini diduga sebagai respon adaptasi terhadap lingkungan, baik dari sisi wadah pemeliharaan dan konsentrasi perlakuan. Kelangsungan hidup ikan dipengaruhi oleh berbagai faktor diantaranya kualitas air (oksigen terlarut, amonia, suhu, $\mathrm{pH}$ ), pakan, umur ikan, lingkungan, dan kondisi kesehatan ikan Adewolu et.,al., (2008).

\section{Kualitas Air}

Kualitas air merupakan media hidup untuk ikan nila yang mempunyai peranan penting. Tabel 2 menunjukkan kulitas air selama pengamatan. Pakan yang diberikan terlalu banyak dan tidak termakan oleh ikan akan terkumpul dan mengendap sehingga mempengaruhi kualitas air, seperti meningkatnya buangan hasil metabolisme ikan.

Tabel 2. Data kualitas air

\begin{tabular}{cccl}
\hline No & Parameter & Kisaran & Optimum \\
\hline 1 & Suhu & $25-28$ & $\begin{array}{l}25-30 \text { (Sucipto dan } \\
\text { Prihartono, 2007) } \\
2\end{array}$ \\
& $\mathrm{pH}$ & $6.1-7.6$ & $\begin{array}{l}6.5-8.5 \text { (Prakoso, } \\
2014)\end{array}$ \\
\hline
\end{tabular}

Pada setiap perlakuan menunjukkan bahwa suhu di wadah pemeliharaan dikategorikan layak untuk kelangsungan hidup ikan. Sucipto dan Prihartono (2007) bahwa lingkungan tumbuh yang paling ideal untuk usaha budidaya ikan nila adalah perairan tawar yang memiliki suhu antara $14-38^{\circ} \mathrm{C}$ atau suhu optimal $25-32^{\circ} \mathrm{C}$. 
Kondisi suhu sangat berpengaruh terhadap kehidupan ikan. Madinawati et.,al (2011) menyatakan bahwa suhu air yang sesuai dapat meningkatkan aktivitas makan ikan, sehingga dapat mempercepat pertumbuhan ikan.

Dalam pemeliharaan selama 30 hari didapat hasil pengukuran $\mathrm{pH}$ bekisar 6.47.67, ini menunjukkan bahwa $\mathrm{pH}$ diwadah pemeliharaan masih relatif aman bagi kehidupan ikan nila yang dipelihara. Prakosos (2014), menyatakan bahwa sebagian besar organisme akuatik sensitif terhadap perubahan $\mathrm{pH}$, dan lebih menyukai pH netral yaitu kisaran 6.5-8.5. Selanjutnya Prakoso (2014) menyatakan proses biokimia perairan, seperti nitrifikasi sangat dipengaruhi oleh $\mathrm{pH}$.

\section{KESIMPULAN DAN SARAN}

\section{Kesimpulan}

Berdasarkan hasil penelitian maka dapat disimpulkan bahwa pemberian tepung cacing tanah dan tepung daun pepaya mampu meningkatkan pertumbuhan ikan nila, dimana pertumbuhan optimum ikan nila terdapat pada perlakuan 4 .

\section{Saran}

Perlu dilakukan penelitian lanjutan untuk mengetahui growth hormone pada ikan hasil pemberian tepung cacing tanah dan tepung pepaya

\section{Ucapan Terima kasih}

Penulis ucapkan terima kasih kepada LPPM UBT sebagai pemberi dana riset pendanaan DIPA UBT Tahun pelaksanaan 2021.

\section{DAFTAR PUSTAKA}

Adewolu M.A, C.A Adenji, A.B Adejobi. 2008. Feed utilization, growth and survival of larias gariepinus (Burchell 1882) fingerlings cultured under different photoperiods. Aquaculture. 283 : 64-67.

Awaludin, Simanjuntak, R.F., Jumsan. 2020. Modifikasi Pakan Buatan untuk
Meningkatkan Pertumbuhan dan Kelangsungan Hidup Udang Windu (Penaeus monodon). Majalah Ilmiah Biologi Biosfera Vo. 37 No.3. DOI: 10.20884/1.mib.2020.37.3.1225

Azis, Simanjuntak, R.F. 2019. Pengaruh Pemberian Pakan Alami yang berbeda terhadap Pertumbuhan Larva Ikan Lele Dumbo (Clarias gariepinus). Jurnal Akuakultur Rawa Indonesia Vol. 7, No 2.

Barrows, F. T and R.W. Hardy. 2001. Nutrition and Feeding. In: G. Wedenmeyer (Eds). Fish Hatchery Management. Second Edition. American Fisheries Society. Bethesda, Maryland. Pp. 497-520.

Chriatianah.O., S. Badirat. 2013. The Effect Of Pawpaw (Carica Papaya) Leave Meal On The Growth Performance And Blood Profile of African Cat Fish. Transnational Journal of Science and Technology July 2013 edition vol.3, No.7

Djajasewaka, H. 1985. Pakan Ikan. C.V Yasaguna, Jakarta. $45 \mathrm{hlm}$.

Effendie, M. I. 2002. Biologi Perikanan. Yayasan Pustaka Nusatama. Yogyakarta.

Hasan, O.D.S. 2000. Pengaruh Pemberian Enzim Papain dalam Pakan Buatan terhadap Pemanfaatan Protein dan Pertumbuhan Benih Ikan Gurame (Osphronemus gouramy Lac.). Tesis. Institut Pertanian Bogor, Bogor. 57 hlm.

Kementrian Kelautan dan Perikanan. 2013. Statistik Menakar Target Ikan Air Tawar Tahun 2013. KKP. http://www.djpb.kkp.go.id/berita.php? $\mathrm{id}=847$. Diakses pada tanggal 9 September 2014.

Madinawati., Serdiati, N., dan eol.2011.Pemberian Pakan Yang Berbeda Terhadap Pertumbuhan dan Kelangsungan Hidup Ikan Lele Dumbo (Clarias gariepinus). Media Litbang Sulteng. Volume 4, Nomor2, Halaman 83-87. 
Natricia WK, Kusnoyo dan MA Alamsjah. 2012. Kombinasi Cacing Sutera (Tubifex SP). Kering dan Tepung Chlorella SP. Sebagai Pakan Tambahan pada Pertumbuhan dan Retensi Protein Benih Ikan Bandeng (Chanos chanos). Journal of Marine and Coastal Science 1(1), 45 - 52.

Prakoso T. 2014. Pengaruh suhu yang berbeda terhadap laju pertumbuhan benih ikan Gurami (Osphronemus gouramy lac) di dalam akuarium [skripsi]. Pangkalan Bun: Program Studi Budidaya Perairan, Fakultas Pertanian, Universitas Antakusuma.

Purbomartono C, Suwarsito. 2019. Pengaruh Ekstrak Daun Pepaya Terhadap Pertumbuhan Dan Sintasa Sidat(Anguilla bicolor) Sistem Bioflok. Universitas Muhammadiyah Purwokerto. ISBN: 978-602-6697-431.

Riyanti, A. 2014. Penambahan Tepung Buah Pepaya Dalam Pakan Terhadap Pertumbuhan dan Efisiensi Pakan pada Ikan Nila Gift Ukuran 3-5 cm. Skripsi.Fakultas Perikanan dan Ilmu Kelautan. Universitas Mulawarman. Samarinda.

Simanjuntak, RF, Abdiani, I.M., Verawati. 2018. Boenrichment Tepung Pepaya (Carica papaya) Dengan Formulasi Pakan Yang Berbeda Pada Performa Pertumbuhan Ikan Nila (Oreochromis niloticus). Jurnal Harpodon Borneo. Vol. 11 No. $02 . \quad$ DOI: https://doi.org/10.35334/harpodon.v11i1. $\underline{540}$

Simanjuntak, RF., Ridwansyah. 2020. Membangun Keterampilan Mahasiswa Perbatasan Kaltara Melalui Teknologi dan Manajemen Pembuatan Pakan Ikan pada Masa Pandemi dan Pasca Covid-19. Jurnal Pengabdian Masyarakat Borneo. Volume 4 Nomor 3. https://doi.org/10.35334/jpmb.v4i2.18 78

Stickney, R.R. 2009. Principles of Warmwater Aquaculture. John Wiley and Sons, Inc. New York. USA.

Sucipto dan Prihartono (2007), Pembesaran Nila Hitam Bangkok di Karamba Jaring Apung, Kolam Air Deras, Kolam Air Tenang dan Karamba. Penerbit Penebar Swadaya, Jakarta.

Tietze. 1997. Tempin Pepaya Buah Terapi Makanan yang Aman dan Murah. Jakarta: Prestasi Pustaka Raya.

Warisno. 2003. Budidaya Perpaya dan Gizi. Jakarta: PT Gremedia Pustaka.

Wirabakti, C.M. 2006. Laju Pertumhan Ikan Nila Merah Yang Dipelira Pada Perairan Rawa Dengan Keramba dan Kolam. http://google.com,/jurnal.upr.ac.id. diakses tanggal 30 Oktor 2012 pukul 16.00 WIB. 